\title{
The effect of metformin on
}

\section{murine and bovine sperm motility parameters}

\author{
D. Londoño-Vásquez*, W. D. Cardona-Maya, J. G. Maldonado-Estrada \\ and M. Olivera-Angel
}

\begin{abstract}
Sperm motility is one of the most relevant parameters related to the fertilizing capability of the spermatozoa. Understanding the anatomy and physiology of sperm flagellum allows for the use of diverse molecules for improving sperm motility, such as metformin. Metformin is a molecule known to stimulate the capability of the cell to uptake and metabolize its energy substrate, acting as an activator of AMP kinase. Its activation leads to the phosphorylation of several substrates implicated in the hyperactivation of the flagellum, as a previous step for the appropriate fertility of the spermatozoa. This paper presents the results of experiments
\end{abstract}

testing the effect of metformin in bull and murine spermatozoa, and reviews aspects related to the use of energy substrate by the spermatozoa, and the molecular mechanisms implicated in metformin role on sperm motility. Since semen analysis is always performed in Eppendorf tubes, whereas the capacitation of sperm cells for in vitro fertilization is performed in drops, we evaluated if there were differences in CASA parameters between sperm cells evaluated in Eppendorf tubes versus drops.

Key words: AMPK; Flagellum; Spermatozoa; Metformin; Sperm motility

\section{Introduction}

Sperm cells are highly differentiated haploid (n) cells, containing three main structures: the head, the intermediate piece, and the flagellum (Cardona Maya and Cadavid Jaramillo, 2004; Samardžija et al., 2008). The sperm head contains the nucleus, containing the haploid genetic material specific of each spermatozoon, which will fuse with the maternal oocyte genome during fertilization for the formation of a new diploid (2n) individual. The acrosome is a crucial component of the sperm cell head. The apical extreme of the acrosome contains a secretory vesicle that is responsible for secreting the enzymes required for the

Daniela LONDOÑO-VÁSQUEZ*, MV, MSc. OHVRI Group, School of Veterinary Medicine, University of Antioquia, Medellin, Colombia (Corresponding author: e-mail: daniela.londonov@udea.edu.co); Walter D. CARDONA-MAYA, Bact., MSc, PhD, Reproduction Group, Department of Microbiology and Parasitology, Medical School, University of Antioquia, Antioquia, Colombia; Juan G. MALDONADO-ESTRADA, MVZ, MSc, PhD, OHVRI Group, School of Veterinary Medicine, University of Antioquia, Medellin, Colombia; Martha OLIVERA-ANGEL, MV., Dr. Sci Agr. Biogenesis Research Group. Department of Agrarian Sciences, University of Antioquia, Antioquia, Colombia 
enzymatic digestion of cumulus cells into the cumulus-oocyte-complex (COC). The cumulus is digested by a coordinated process of exocytosis, comprising enzymes such as hyaluronidase, acrosin, esterase, and acid hydrolases. All these enzymes are responsible for the acrosome reaction that takes place during fertilization (Amann and Waberski, 2014; Cardona Maya and Cadavid Jaramillo, 2004; Olivera et al., 2006; Majić Balić et al., 2012; Vince et al., 2018; Žura Žaja et al., 2019a). The sperm flagellum is an organ required for sperm motility, containing four components: the cervix or connecting piece, the intermediate piece, the main piece, and the terminal piece (Cardona Maya and Cadavid Jaramillo, 2004). The connecting piece contains the basal body and connects the tail to the head of the spermatozoa (Cardona Maya and Cadavid Jaramillo, 2004), the intermediate piece contains the mitochondria, organelles responsible for providing the energy required for sperm motility. Mitochondria are organized in a tandem helicoidal pattern in the external dense fibers. The main and final pieces are responsible for generating the sperm motility in a flagellum wave (Amann and Waberski, 2014).

Sperm cell motility is a crucial function of spermatozoa (Heuser er al., 2009; Hurtado et al., 2016; Žura Žaja et al., $2019 b)$, providing the capability to move progressively forward, to travel along the female reproductive tract and the fertilization site in the oviduct to fertilize the oocyte (Hurtado de Llera et al., 2012; Rodriguez-Martinez, 2019). Spermatozoa must overcome several barriers such as the cervical mucus and endometrial folds, while activating the capacitation process, which is related to the capability of modulating the endometrial environment during its travel along the endometrial surface. In order to accomplish this, sperm cells must move through the cervical mucus, and once in the female reproductive tract, they undergo a series of processes known as sperm capacitation, which is regulated by the uterine microenvironment (Hurtado de Llera et al., 2015). The availability of an energy source for ATP production from glucose and fructose is the limiting factor for sperm hyperactivation. The GLUT3 and GLUT5 transporters, located in the intermediate piece, are necessary for their respective translocation into the sperm cytosol (King, 2016). These energy sources enter oxidative phosphorylation through the aerobic pathway into the mitochondria, resulting in the generation of 30 ATP molecules, whereas the anaerobic glycolysis pathway takes place in the flagellum, generating two ATP molecules for each molecule of oxidized glucose (Lehti and Sironen, 2016; Linck et al., 2016).

The interaction of several ions and molecules present in the seminal fluid and the female reproductive tract (King, 2016) is required for these processes of flagellum movement to take place.

Metformin is a biguanide molecule regularly used for the treatment of Type2 diabetes mellitus, and recently its use has expanded beyond endocrinology to the field of reproductive biology because of its AMPK phosphorylation promoting effect (Nguyen et al., 2016). Metformin also reduces the level of oxidative stress and lipid peroxidation by increasing the release of cellular scavenger molecules, including glutathione, superoxide dismutase, catalase, and glutathione peroxidase (Nguyen, 2019)' and it stimulates the expression of antioxidant genes (Nrf2) (Nguyen et al., 2016; Lehti and Sironen, 2017). The objective of the present study was to evaluate the effect of metformin on sperm cell parameters using thawed semen from fertile bulls and fresh semen from mature mice. Also, because semen analysis is always performed in Eppendorf tubes, whereas the capacitation of sperm cells for in 
vitro fertilization is performed in drops, we evaluated if there were differences in CASA parameters between sperm cells evaluated in Eppendorf tubes versus drops.

\section{Materials and methods}

Study 1. Evaluation of the effect of metformin on the sperm motility of thawed bovine spermatozoa.

Type of study: Experimental study.

Sample: straws of three different Bulls (two Holstein and one red Brahman) were used. After thawing, experiments were performed in triplicate.

Media culture preparation. In this experiment, we used the F-Talp culture medium prepared by dilution in a sterile aqueous solution and stored at $4^{\circ} \mathrm{C}$ until use. Three hours before sperm cell incubation, the culture medium was equilibrated at $37^{\circ} \mathrm{C}, 95 \%$ relative humidity, and $5 \% \mathrm{CO}_{2}$ in a humidified atmosphere. Metformin chlorhydrate (Pharma) was diluted in sterile phosphate-buffered salt (PBS) solution.

Sample processing: straws were thawed at $35^{\circ} \mathrm{C} / 30$ seconds. Then, motile spermatozoa were obtained by centrifugation on a mini-percoll gradient for 10 minutes. The pellet was recovered and diluted in F-Talp medium and added with metformin at seven different concentrations: $5000 \mu \mathrm{M}, 500 \mu \mathrm{M}, 50$ $\mu \mathrm{M}, 5 \mu \mathrm{M}, 0.5 \mu \mathrm{M}$, and $0.05 \mu \mathrm{M}$. Sperm cells were incubated at $37^{\circ} \mathrm{C} / 30$ minutes, and progressive motility was evaluated under the light microscope using subjective criteria for semen motility. All evaluations were performed by the same trained veterinarian.

Study 2. Evaluation of the effect of metformin on CASA parameters of fresh murine spermatozoa.

Type of study. Experimental study.

Sample: Wild Type C57BL/6 x DBA2 mouse males were selected $(n=12)$ and divided into four groups (replicas). Mice were kept under a controlled photoperiod of light between 8:00 to 21:00 hours, food, and water ad libitum. All procedures were performed with the consent of the Universidad del Pais Vasco Institutional Committee for Bioethics in Research on Animal Subjects (Act \# M20_2018_247, CEEA- UPV/EHU).

Preparation of culture medium: Human Tubal Medium (HTF) was diluted in sterile water and stored at $4^{\circ} \mathrm{C}$ until use. Before use, HTF was warmed at $37^{\circ} \mathrm{C}$, $5 \% \mathrm{CO}_{2}$, and $95 \%$ relative humidity in a humidified atmosphere for three hours. Metformin chlorhydrate (Pharma) was diluted to the desired concentration in sterile Phosphate Saline Buffer (PBS).

Semen collection and evaluation of sperm cell concentration: Mice aged 3 to 4 months were selected as semen donors and were euthanized by cervical dislocation. Testicles and epididymis were recovered from the scrotum under the stereomicroscope (10X magnification). The fat surrounding the deferent conduct was removed as much as possible, and the umbilical artery and vein were removed to avoid blood contamination of samples. The dissected tissue was placed on $500 \mu \mathrm{L} \mathrm{HTF}$, soft pressure was exerted on the epididymus to extract the semen, and the total volume (semen + HTF medium) was collected into 1.5 $\mathrm{ml}$ sterile Eppendorf tubes. To calculate sperm cell concentration, $50 \mu \mathrm{L}$ HTFcontaining semen was diluted in an equal volume of water, and $10 \mu \mathrm{L}$ was placed into a Makler chamber. Sperm cell counts were conducted by counting the number of sperm cells present in ten randomly selected grids. Sperm cell concentration was adjusted to $2 \times 10^{6} /$ drop.

Quantification of sperm cell parameters: Sperm cells were added with $5000 \mu \mathrm{M}$, $500 \mu \mathrm{M}, 50 \mu \mathrm{M}, 5 \mu \mathrm{M}, 0,5 \mu \mathrm{M}, 0,05$ $\mu \mathrm{M}$ metformin and were incubated in Eppendorf tubes for 0, 30, and 60 minutes at $37^{\circ} \mathrm{C}, 5 \% \quad \mathrm{CO}_{2}$, and $95 \%$ relative 
humidity in a humidified atmosphere. The drop-containing semen was also evaluated after 60 minutes of incubation. Sperm cell parameters were immediately evaluated after finishing each time-point of evaluation using Sperm Class Analyzer (SCA), according to the following parameters:

- Curvilineal Velocity (VCL; $\mu \mathrm{m} / \mathrm{s}$ ): the time-averaged velocity along the curvilinear path of the spermatozoa (actual speed of the sperm cell).

- Straight-line velocity (VSL; $\mu \mathrm{m} / \mathrm{s})$ : the straight line distance between the original point and the last point of a distance traveled by spermatozoa, allowing information on the net distance gain of the trajectory.

- Average velocity (VAP; $\mu \mathrm{m} / \mathrm{s})$ : the average distance traveled by the spermatozoa through the circular trajectory.

- Linearity Index (LIN): the percentage relationship between VSL and VCL. LIN = (VSL/ VCL) ${ }^{*} 100$

- Straightness of the average path (STR): the percentage relationship between VSL and VAP. STR = $(\mathrm{VSL} / \mathrm{VAP})^{*} 100$

- Oscillation Index (WOB): the percentage relationship between VAP y VCL.

- $\quad \mathrm{WOB}=(\mathrm{VAP} / \mathrm{VCL})^{*} 100$

- Lateral head $(\mu \mathrm{m})$ : width of trajectory variation of the sperm head about VAP.

- Beat frequency $(\mathrm{Hz})$ : frequency of lateral head sperm movements.

\section{Statistical analysis}

For study 1, data were analysed by non-parametric paired-ANOVA. Data from study 2 were subjected to descriptive statistics established for each CASA parameter. Comparisons between 0 and 60 minutes for each parameter were evaluated by the Kruskal-Wallis Test. The effect of metformin on each CASA parameter was evaluated by the Student t-test. Statistical significant differences were considered at $P<0.05$. Differences in motility parameters using Eppendorf tubes or drop at 0 and 60 minutes of incubations were evaluated by the Kruskal-Wallis test. Data were analyzed using the R statistic software.

\section{Results}

In study 1 , the progressive motility of thawed bovine spermatozoa after 30 minutes of incubation was significantly reduced at all concentrations of metformin evaluated compared to the control (Figure 1). When analyzed altogether, progressive motility was significantly reduced in spermatozoa exposed to $0.5 \mu \mathrm{M}$ and $5000 \mu \mathrm{M}$, compared to the control (Figure 2).

In study 2, when VSL, VAP and BCF values were evaluated according to its incubation in drops or wells, spermatozoa incubated with metformin presented significantly higher values compared to spermatozoa evaluated in wells. Control samples exhibited lower values for VSL (13.416), VAP (22.421), and BCF (3.997) (Table 1). Also, spermatozoa from the control group presented a significantly lower LIN value when incubated in drops, compared to spermatozoa incubated in wells (Table 1 ).

For STR, samples evaluated in drops had the lowest values compared to samples incubated in Eppendorf microtubes $(P<0.05)$. WOB values were higher in spermatozoa incubated in Eppendorf tubes compared to control spermatozoa (Table 1). Metformin did not significantly affect spermatozoa CASA values, with the exception of WOB values that showed significantly different values at 60 minutes compared to values 


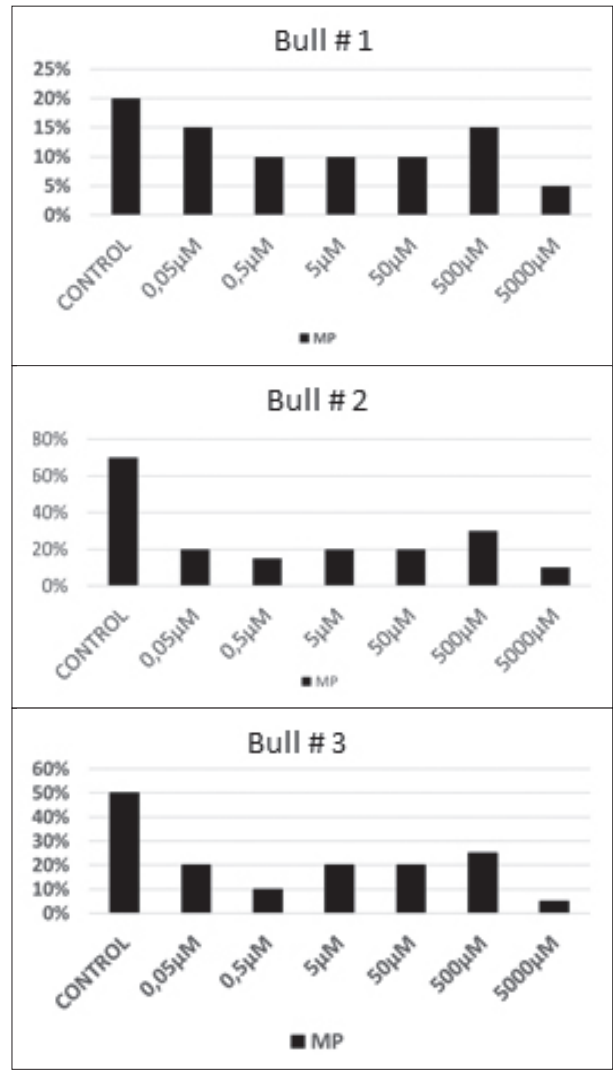

Figure 1. Effect of 30 minutes of metformin addition on the percentage of progressive motility of spermatozoa from the semen of three bulls

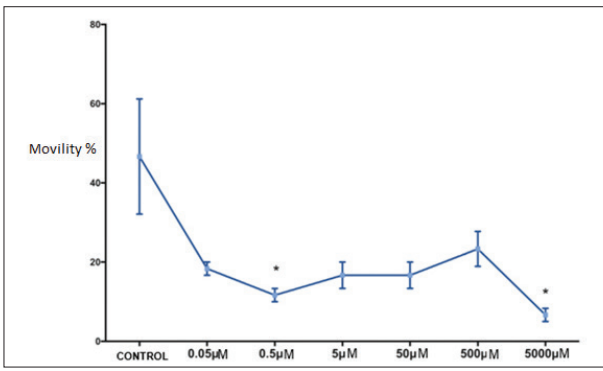

Figure 2. Comparison of the effect of Metformin on the percentage of progressive motility of spermatozoa from the semen of three bulls. ${ }^{*}=$ $P<0.05$ (Friedman test)

at 0 minutes, resulting in a significant increase in spermatozoa oscillation $(P<0.05)$ (Table 2).

In VSL and VAP, parameters that evaluate the beating frequency, samples incubated in drops showed higher values compared to the control $(P<0.05)$. For the variable LIN, incubation in Eppendorf tubes showed the highest values compared to the control and drops (Table 1).

For STR values, values in Eppendorf tubes were higher, but drops were significantly higher than in the control. The WOB parameters showed that spermatozoa incubated in Eppendorf

Table 1. Effect of metformin on mouse permatozoa quality parameters evaluated after 60 minutes of incubation (mean value)

\begin{tabular}{|c|c|c|c|c|}
\multirow{2}{*}{ Parameter } & \multicolumn{2}{|c|}{ Metformin } & \multirow{2}{*}{ Control } & \multirow{2}{*}{$\boldsymbol{P}$-value } \\
\cline { 2 - 3 } & Eppendorf & Drop & & \\
\hline VCL & $45.621 \pm 8.400^{\mathrm{a}}$ & $49.356 \pm 12.658^{\mathrm{a}}$ & $44.920 \pm 9.968^{\mathrm{a}}$ & 0.3462 \\
\hline VSL & $15.127 \pm 4.236^{\mathrm{ab}}$ & $16.864 \pm 5.973^{\mathrm{a}}$ & $13.416 \pm 3.932^{\mathrm{b}}$ & $\mathbf{0 . 0 2 3 5}$ \\
\hline VAP & $24.154 \pm 4.930^{\mathrm{ab}}$ & $26.256 \pm 7.084^{\mathrm{a}}$ & $22.421 \pm 5.206^{\mathrm{b}}$ & $\mathbf{0 . 0 2 3 8}$ \\
\hline LIN & $35.125 \pm 7.263^{\mathrm{ab}}$ & $35.068 \pm 12.353^{\mathrm{a}}$ & $31.517 \pm 5.382^{\mathrm{b}}$ & $\mathbf{0 . 0 2 1 8}$ \\
\hline STR & $64.328 \pm 7.880^{\mathrm{a}}$ & $50.830 \pm 11.729^{\mathrm{b}}$ & $61.663 \pm 5.684^{\mathrm{a}}$ & $\mathbf{0 . 0 0 0 0}$ \\
\hline WOB & $53.105 \pm 5.733^{\mathrm{a}}$ & $52.710 \pm 7.050^{\mathrm{ab}}$ & $50.657 \pm 4.575^{\mathrm{b}}$ & $\mathbf{0 . 0 1 9 3}$ \\
\hline Head lateral & $2.294 \pm 0.348^{\mathrm{a}}$ & $2.280 \pm 0.831^{\mathrm{a}}$ & $2.270 \pm 0.442^{\mathrm{a}}$ & 0.9677 \\
\hline Beat frequency & $4.422 \pm 1.040^{\mathrm{ab}}$ & $4.824 \pm 1.063^{\mathrm{a}}$ & $3.997 \pm 0.882^{\mathrm{b}}$ & $\mathbf{0 . 0 4 0 7}$ \\
\hline
\end{tabular}

Columns with different letters indicate statistically significant differences (Kruskal-Wallis test). Control = time 0 , Eppendorf and drop, after $60 \mathrm{~min}$ of incubation. VCL: curvilinear velocity $(\mu \mathrm{m} / \mathrm{s})$. VSL: straight-line velocity $(\mu \mathrm{m} / \mathrm{s})$. VAP: average velocity $(\mu \mathrm{m} / \mathrm{s})$. LIN: linearity index LIN $=(\mathrm{VSL} / \mathrm{VCL}) * 100$. STR: Straightness of the average path $((\mathrm{VSL} /$ VAP $\left.)^{*} 100\right)$. WOB: oscillation index: $=(\mathrm{VAP} / \mathrm{VCL})^{*} 100$. Lateral head $(\mu \mathrm{m})$. Beat frequency $(\mathrm{Hz})$. 


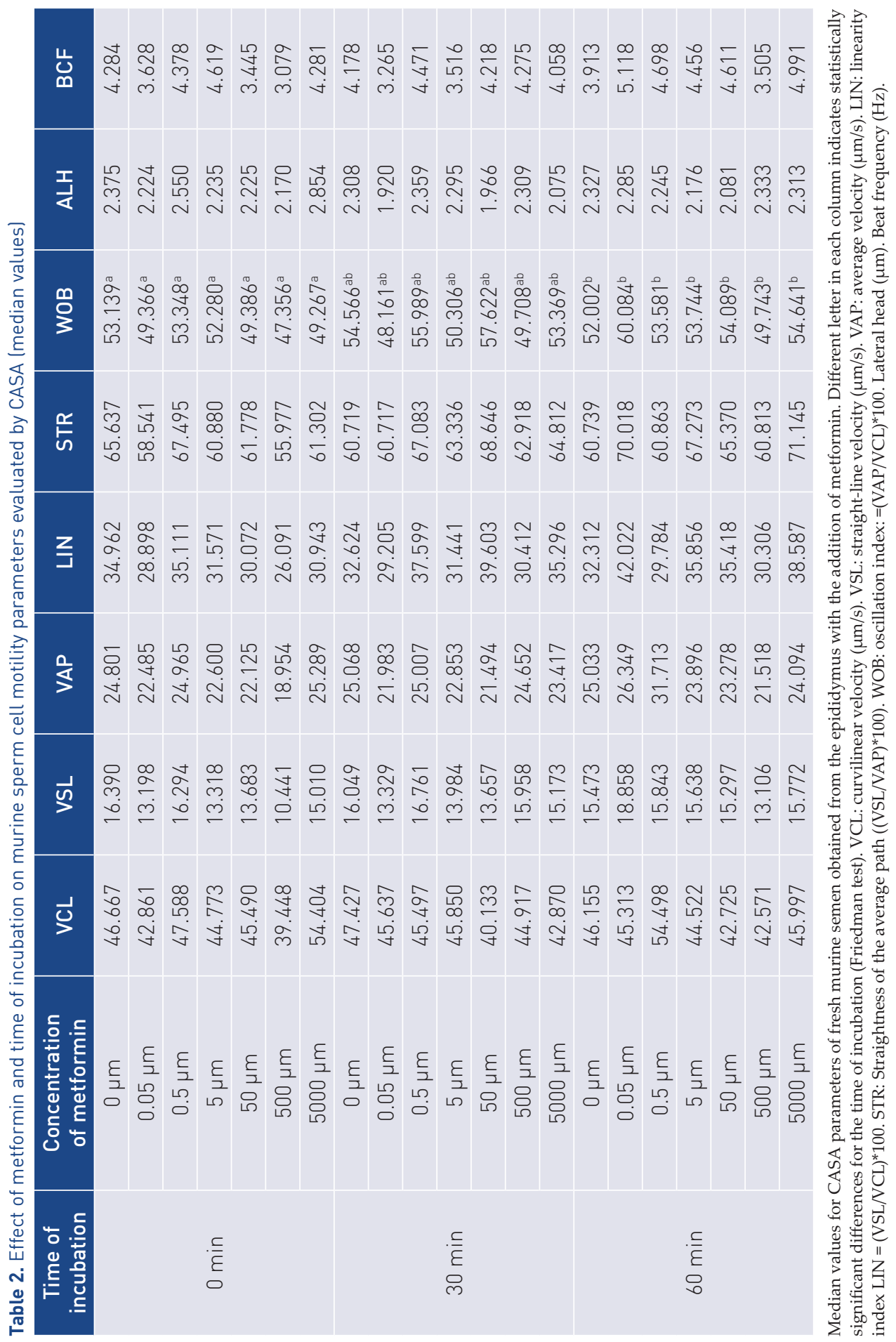


tubes exhibited higher values $(P<0.05)$ compared to the control (Table 1).

\section{Discussion}

This study found that metformin did not affect motility parameters in thawed semen from bulls nor in fresh semen isolated from the epididymus of mature mice. On the contrary, in most cases, sperm cell motility was significantly reduced when incubated with metformin. Metformin is a compound used for the treatment of diabetes mellitus, but its effect in semen parameters has not been studied. According to the scientific literature, this is the first study to evaluate the use of metformin in bull and mice spermatozoa. The first finding we have to explain is why to compare two surfaces for evaluating the effect of metformin: the drop method and the microtube method.

The reduction in sperm cell motility found in the present study could be due to the sustained activation of AMPK, which could lead to a dysregulation of sperm cell metabolism by the activation of catalytic pathways implicated in the generation of ATP (Nguyen, 2019), although this activity was not measured here. However, metformin was reported to reduce human sperm cell motility, with a concomitant inhibition of PKA signaling and PKA-mediated signaling pathways, though with no effect on cell viability. Metformin has been reported to significantly impair human sperm cell motility parameters (CalleGuisado et al., 2019). Similar results were observed when metformin was used in wild boar spermatozoa added to $5000 \mu \mathrm{M}$ metformin for two hours (Hurtado de Llera et al., 2012, 2016). On the contrary, when evaluated in Gallus gallus, spermatozoa, motility, viability, and acrosome reaction were significantly impaired when added with AMPK activators (Nguyen et al., 2014).
The evaluation of the effect of recipient type on sperm cell motility performed in the present study showed that incubating sperm cells in Eppendorf tubes or directly into a medium drop can modify the results of metformin on sperm cell motility parameters. In this study, LIN, STR, and WOB values were significantly increased, whereas VCL, VSL, and VAP were significantly decreased when sperm cells were cultured using Eppendorf tubes. These results may indicate that the estimation of sperm cell motility parameters evaluated by CASA could be affected when using Eppendorf tubes. Further experiments are needed to evaluate the effect of the type of device used for storage and incubation could affect the results of CASA parameters.

Overall, no effects of metformin on fresh murine sperm cell motility parameters evaluated by CASA were found. Bertoldo et al. (2014) reported that metformin did not affect fresh semen motility parameters, although 5000 $\mu \mathrm{M}$ metformin significantly decreased sperm cell motility compared to the control group. On the other hand, adding metformin to semen for 30 minutes significantly reduced sperm cell motility compared to fresh semen, which was corroborated in this study. Those authors also reported that metformin did not affect sperm cell viability or acrosome integrity (Bertoldo et al., 2014). Similar results to those here were found when $10 \mathrm{mM}$ metformin was added to human sperm cells further evaluated at 8 and 20 hours after metformin addition. The population of motile spermatozoa was significantly reduced proportionate to the time of incubation, VCL, VSL, VAP, LIN, and STR were significantly reduced, with no effect on the parameters WOB, $\mathrm{BCF}$, and ALH. These results are contrary to the findings presented here, where only WOB was affected by the addition of metformin. 
The rationale for the addition of metformin in the present study was its effect on AMPK and its activation relationship with sperm cell motility. However, we found no effects of metformin on sperm cell motility parameters in either thawed bovine semen evaluated by light microscopy or in fresh murine semen evaluated by CASA. On the contrary, metformin significantly reduced sperm cell motility parameters in bull spermatozoa after thawing. In conclusion, metformin did not improve sperm cell motility parameters in murine spermatozoa but significantly reduced the motility of bull spermatozoa.

\section{Acknowledgments}

Special thanks to the Universita del Pais Vasco, Barcelona, for providing the facilities and animals used in the study.

\section{References}

1. AMANN, R.P. and D. WABERSKI(2014): Computerassisted sperm analysis (CASA): capabilities and potential developments. Theriogenology 81, 5-17 e11-13.

2. BERTOLDO, M. J., E. GUIBERT, P. TARTARIN, V. GUILLORY and P. FROMENT (2014): Effect of metformin on the fertilizing ability of mouse spermatozoa. Cryobiology 68, 262-268.

3. CALLE-GUISADO, V., L. GONZALEZFERNANDEZ, D. MARTIN-HIDALGO, L. GARCIA-MARIN and M. BRAGADO (2019): Metformin inhibits human spermatozoa motility and signalling pathways mediated by protein kinase $\mathrm{A}$ and tyrosine phosphorylation without affecting mitochondrial function. Reprod. Fertil. Develop. 31, 787-795.

4. CARDONA MAYA, W. D. and A. P. Cadavid Jaramillo (2004): [Intergamete complementarity: short review]. Arch. Esp. Urol. 57, 1107-1112.

5. HEUSER, T., M. RAYTCHEV, J. KRELL, M. E. PORTER and D. NICASTRO (2009): The dynein regulatory complex is the nexin link and a major regulatory node in cilia and flagella. J. Cell Biol. 187, 921-933.

6. HURTADO DE LLERA, A., D. MARTINHIDALGO, M. GIL, L. GARCIA-MARIN and M. BRAGADO (2016): New insights into transduction pathways that regulate boar sperm function. Theriogenology 85, 12-20.

7. HURTADO DE LLERA, A., D. MARTINHIDALGO, M. C. GIL, L. J. GARCIA-MARIN and
M. J. BRAGADO (2012): AMP-activated kinase AMPK is expressed in boar spermatozoa and regulates motility. PloS one 7(6), e38840.

8. HURTADO DE LLERA, A., D. MARTINHIDALGO, M. C. GIL, L. J. GARCIA-MARIN and M. J. BRAGADO (2015): AMPK up-activation reduces motility and regulates other functions of boar spermatozoa. Mol Hum Reprod, 21, 31-45.

9. KING, S. M. (2016): Axonemal Dynein Arms. Cold Spring Harb Perspect Biol, 8 (11), a028100. doi:10.1101/cshperspect.a028100

10. LEHTI, M. S. and A. SIRONEN (2016): Formation and function of the manchette and flagellum during spermatogenesis. Reproduction 151, R43-54.

11. LEHTI, M. S. and A. SIRONEN (2017): Formation and function of sperm tail structures in association with sperm motility defects. Biol Reprod, 97, 522-536.

12. LINCK, R. W., H. CHEMES and D. F.ALBERTINI (2016): The axoneme: the propulsive engine of spermatozoa and cilia and associated ciliopathies leading to infertility. J. Assist. Reprod. Genet. 33, 141-156.

13. MAJIĆ BALIĆ, I., S. MILINKOVIĆ-TUR, M. SAMARDŽIJA and S. VINCE (2012): Effect of age and environmental factors on semen quality, glutathione peroxidase activity and oxidative parameters in simmental bulls. Theriogenology 78, 423-431.

14. NGUYEN, T. M., S. ALVES, I. GRASSEAU, S. METAYER-COUSTARD, C. PRAUD, P. FROMENT and E. BLESBOIS (2014): Central role of 5'-AMPactivated protein kinase in chicken sperm functions. Biol. Reprod. 91, 121.

15. NGUYEN, T. M., P. FROMENT, Y. COMBARNOUS and E. BLESBOIS (2016): [AMPK, regulator of sperm energy and functions]. Med. Sci. (Paris), 32, 491-496.

16. NGUYEN, T. M. D. (2019): Role of AMPK in mammals reproduction: Specific controls and whole-body energy sensing. C R Biol, 342, 1-6. doi:10.1016/j.crvi.2018.10.003

17. OLIVERA, M., RUIZ, T., A. TARAZONA and C. GIRALDO (2006): [The sperm cell: from eyaculation to fertilization]. Rev. Colomb. de Cienc. Pecu, 19, 426-436.

18. RODRIGUEZ-MARTINEZ, H. (2019): Semen evaluation: can we forecast fertility? Vet. stn. 50, 293-305.

19. SAMARDŽIJA, M., M. KARADJOLE, I. GETZ, Z. MAKEK, M. CERGOLJ and T. DOBRANIĆ (2006): Effects of bovine spermatozoa preparation on embryonic development in vitro. Reprod. Biol. Endocrinol. 4; 58

20. VINCE, S., I. ŽURA ŽAJA, M. SAMARDŽIJA, I. MAJIĆ BALIĆ, M. VILIĆ, D. ĐURIČIĆ, H. VALPOTIĆ, F. MARKOVIĆ and S. MILINKOVIĆTUR (2018): Age-related differences of semen quality, seminal plasma, and spermatozoa antioxidative and oxidative stress variables in bulls during cold and warm periods of the year. Animal 12, 559-568.

21. ŽURA ŽAJA, I., I. ŠVUB, S. MILINKOVIĆ-TUR, S. VINCE, H. VALPOTIĆ, D. ĐURIČIĆ, S. ČIPČIĆ 
and M. SAMARDŽIJA (2019a): Biochemical parameters of seminal plasma in domestic animals and humans. Vet. stn. 50, 223-237. (In Croatian)

22. ŽURA ŽAJA, I., A. SLUGANOVIĆ, M. SAMARDŽIJA, S. MILINKOVIĆ-TUR, T.
DOBRANIĆ, S. STRELEC, D. ĐURIČIĆ, H. VALPOTIĆ and S. VINCE (2019b): The effects of oxidative stress on the male reproductive system and mechanisms of antioxidant protection. Vet. stn. 50, 43-54. (In Croatian).

\section{Učinak metformina na parametre pokretljivosti sperme miševa i goveda}

Daniela LONDOÑO-VÁSQUEZ*, MV, MSc. OHVRI Group, School of Veterinary Medicine, University of Antioquia, Medellin, Colombia (Corresponding author: e-mail: daniela.londonov@ udea.edu.co); Walter D. CARDONA-MAYA, Bact., MSc, PhD, Reproduction Group, Department of Microbiology and Parasitology, Medical School, University of Antioquia, Antioquia, Colombia; Juan G. MALDONADO-ESTRADA, MVZ, MSc, PhD, OHVRI Group, School of Veterinary Medicine, University of Antioquia, Medellin, Colombia; Martha OLIVERA-ANGEL, MV., Dr. Sci Agr. Biogenesis Research Group. Department of Agrarian Sciences, University of Antioquia, Antioquia, Colombia

Pokretljivost sperme jedan je od najrelevantnijih parametara povezanih s oplodnim kapacitetom spermija. Razumijevanje anatomije i fiziologije flageluma spermija omogućuje uporabu različitih molekula za poboljšanje pokretljivosti sperme poput metformina. Metformin je molekula za koju je poznato da stimulira sposobnost stanice da unese i metabolizira svoj energetski supstrat, djelujući kao aktivator protein-kinaze aktivirane mitogenom (MAPK), čija aktivacija dovodi do fosforilacije nekoliko supstrata uključenih u hiperaktivaciju flageluma, kao prethodni korak za odgovarajuću plodnost spermija. U ovom su radu predstavljeni rezultati pokusa ispitivanja učinka metformina na spermije bika i miša te pregled onih aspekata povezanih s uporabom energetskog supstrata od strane spermija te molekularnih mehanizama uključenih $u$ ulogu metformina $u$ pokretljivost spreme. $\mathrm{Uz}$ to, obzirom da se analiza spermija uvijek obavlja u eppendorf epruvetama, dok se kapacitacija spermija za in vitro oplodnju obavlja u kapljicama, željeli bismo ocijeniti postoje li razlike u CASA (računalno potpomognuta analiza spermija) parametrima između spermija procijenjenih $u$ eppendorf epruvetama u usporedbi s kapljicama.

Ključne riječi: $M A P K$, flagelum, spermiji, metformin, pokretliivost sperme 